\title{
An economic analysis of landowner propensity for woodlot management and harvesting in northwestern Saskatchewan
}

\author{
by Fiona J. Salkie, Martin K. Luckert and William E. Phillips ${ }^{1}$
}

The recent development of new processing facilities in Meadow Lake, Saskatchewan has created a long-term market for timber in the region. Although these processing facilities are currently supplied by crown timber reserves, increasing pressure on public forest resources from multiple users has caused processors to consider private woodlots as a supplemental source of fibre. A survey was undertaken to investigate conditions under which landowners may respond to the emerging demand by managing their timber resources for harvest and sale.

Survey results indicate that, although virtually no management or harvesting has occurred in the past, approximately half of those interviewed would consider timber management and harvesting in the future. Logit analysis identified landowner characteristics that were related to landowners' willingness to consider forest management and harvest in the future and the likelihood that they would consider a timber contract. Significant characteristics of landowners in influencing the propensity to manage and harvest their woodlots included: the diversity of farm operations, the length of family tenure of the land, the number of ways respondents use their forest land, and area of forest owned. A preferred timber contract was identified as having: a duration of 1 to 5 years, young growth established at the end of the contract term, and payments for harvesting and management services made through a crop share arrangement.

Key words: private forestry, forest economics, timber contracts, landowner characteristics, woodlot management
La récente construction de nouvelles usines de transformation à Meadow Lake en Saskatchewan a créé un marché à long terme pour le bois dans cette région. Même si ces usines de transformation sont actuellement approvisionnées à partir de réserves publiques de bois, les pressions de plus en plus grandes exercées de la part de multiples usagers sur les ressources forestières publiques ont forcé les industriels à envisager d'utiliser les boisés privés en tant que source de fibres. Un sondage a été effectué afin d'identifier les conditions qui inciteraient les propriétaires à répondre à cette demande croissante par l'aménagement de leurs ressources forestières à des fins de récolte et de vente.

Les résultats du sondage indiquent que, même si presque qu'aucun aménagement ou aucune récolte n'a eu lieu dans le passé, près de la moitié des personnes interrogées considéreraient aménager leurs boisés et vendre du bois dans l'avenir. L'analyse des données a permis d'identifier les caractéristiques des propriétaires reliées à leur intérêt à aménager leurs boisés et à effectuer une coupe dans l'avenir, et d'évaluer la possibilité d'envisager de signer un contrat d'approvisionnement. Les caractéristiques significatives des propriétaire ayant une influence sur leur propension à aménager et à couper leurs boisés étaient: la diversité de leurs opérations agricoles, le nombre d'années de possession des terres par la famille, les diverses façons selon lesquelles les répondants utilisent leurs boisés, et la superficie des boisés détenus. Le contrat type idéal d'approvisionnement en bois devrait comprendre: une durée de 1 à 5 ans, la présence d'un jeune peuplement à la fin du contrat, et le paiement des frais de récolte et de gestion établi selon un processus d'étalement de la récolte.

Mots clés: forêt privée, économie forestière, contrats d'approvisionnement, caractéristiques du propriétaire, aménagement du boisé

\section{Introduction}

Although 389000 ha ( 961000 acres) of Saskatchewan's productive, non-reserved forest land is privately owned, few markets have developed for private timber. There have been small markets for firewood and rough lumber but limited opportunities for large scale fibre sales. Historically, aspen (Populus tremuloides Michx.), which makes up a large portion of Saskatchewan forests, was considered a "weed species" with little commercial value. However, recent technological innovations have caused aspen to become a commercially valuable species. Accordingly, a pulp mill was constructed in Meadow Lake, Saskatchewan that utilizes aspen as its primary input. This mill has created a long-term demand for aspen in the northwest region of the province. Although industrial forest products companies are allocated crown timber through Forest Management Licence Agreements (FMLA), increasing pressure from other users of the forest, such as aboriginal and environmental groups, has placed uncertainty on the long-term availability of current fibre allocations. This has caused industrial timber managers to look towards private woodlots as a potential long-term source of fibre.

This study was undertaken to assess whether woodlot owners would respond to emerging timber markets and to investigate mechanisms that could be used to overcome some of the factors that may have impeded the development of a private forest sector. Three goals were identified for the study: 1) to identify landowner characteristics that may be related to willingness to consider timber management ${ }^{2} /$ harvest in the future; 2 ) to investigate the use of various contracts to encourage private forest management and sustainable timber harvesting; and 3) to consider the results of this analysis within the context of government policy and other factors that affect land use decisions.

'Research Associate, Associate Professor, and Professor respectively, Department of Rural Economy, University of Alberta, Edmonton, Alberta, Canada.

${ }^{2}$ Management is a term used in this paper in a broad context and simply refers to making and carrying out decisions and plans to meet peoples goals and aims (Duerr et al. 1979). 


\section{Background}

A number of factors support the development of a private forest sector in Saskatchewan. Most privately owned forest land in Saskatchewan is owned by farmers. Thus, the opportunity cost of labour in the winter is relatively low and diversification into woodlot management may be complementary to existing agricultural operations. Furthermore, private forests are generally located on the forestry-agriculture fringe and are accessible through existing transportation infrastructure and frequently in close proximity to processing facilities.

Despite these favourable conditions, several factors may have impeded the development of private timber markets. A number of government policies, ranging from forest tenure to agriculture subsidies and taxation, may affect decisions to manage and harvest timber in Saskatchewan. Tenure agreements generally require companies to establish value added processing facilities. This requirement has led to vertically integrated forest products firms and a general absence of log markets for woodlot owners ${ }^{3}$. Furthermore, tenure policies may discourage licensees from considering alternative sources of fibre supply. Allocation of public timber may provide industrial forest product firms with enough public timber to internally supply their operations, particularly because tenure agreements contain "use it or lose it" clauses which encourage industrial forest processors to use all of their annual cut (Farm Woodlot Association of Saskatchewan 1991). Also, tenure is generally allocated in such a way that industrial forest processing facilities are spatially separated, which may result in the formation of spatial monopsonies. Accordingly, prices offered for wood may be insufficient to stimulate extensive woodlot management. Finally, stumpage prices (royalty or returns to crown land) charged to the forest industry by the provincial government for Crown timber may be lower than comparable competitive returns required by private landowners. Accordingly, woodlot owners may have little incentive to undertake forest related activities.

A number of agricultural policies also affect land use decisions on private land. The magnitude of payouts through agricultural programs suggest that such subsidies have considerable impact on land use decisions. In 1992 gross direct payments to producers in Saskatchewan amounted to nearly $\$ 630$ million or $25.07 \%$ of total farm cash receipts, while net direct payments totalled almost $\$ 444$ million or $65.59 \%$ of net farm cash income (Statistics Canada 1993). Agricultural subsidies may discourage farm woodlot development because under subsidy programs such as the Gross Revenue Insurance Program (GRIP), the Net Income Stabilization Account (NISA) or the Canada-Saskatchewan Crop Insurance Corporation programs, farm woodlots are not recognized as a farm enterprise. Furthermore, landowners may have difficulty including woodlot income in loan applications to financial agencies such as the Agriculture Credit Corporation - Saskatchewan (ACS).

Some government programs exist which encourage woodlot management; however, their size and extent are very small compared to agricultural programs. The Prairie Farm Rehabilitation

\footnotetext{
${ }^{3}$ An example of a vertically integrated firm would be one in which silvicultural, harvesting, and wood processing activities are conducted by a single firm, as opposed to a case where the activities are allocated to separate firms. There are no visible markets for logs in the case of a vertically integrated firm since movement of logs from harvest to processing are dealt with internally by a single firm.
}

Administration (PFRA) provides funding and planning assistance to help farmers plant shelterbelts and return cultivated land to permanent cover. However, no one in Saskatchewan has used the permanent cover program to plant trees in a block of land (block plantings), as opposed to linear strip plantings ${ }^{4}$. The Save Our Soils program provided funding for field shelterbelts and trees were available through the Wildlife Habitat Protection Act for block plantings. Furthermore, the Canadian Forest Service, through the Canada-Saskatchewan Partnership Agreement in Forestry, provides direct federal funding for extension services to assist woodlot managers, and incentive funds for forest improvements. However, although $\$ 65932$ was provided for extension services to woodlot owners in Saskatchewan in 1992 , less than $\$ 6500$ was paid directly to landowners for forest management activities ${ }^{5}$.

Another factor inhibiting woodlot development may be the small size of many woodlots which may prevent landowners from achieving economies of scale in harvesting and management. Also, wood processors may face high transactions costs when purchasing wood from many small sellers or harvesting small parcels of private land. Information exchange problems may also impede the development of private timber markets. On the supply side, woodlot owners may be unaware of potential timber markets and may not have the knowledge required to manage their forests given that technology has only recently made aspen valuable. On the demand side, wood processors may not know of woodlot owners who are interested in selling fibre.

Public policy may be able to correct some of these problems and influence the development of private timber markets. However, to direct policy in an optimal manner, policy makers must understand the motivations of woodlot owners, their attitudes towards various policy options, and their likely response to policy initiatives. Little is known about motivations of woodlot owners in Saskatchewan with regards to their forest harvesting and management decisions. Earlier studies have concentrated on monetary returns to landowners and have tended to ignore nonpecuniary benefits that can be derived from private forests ${ }^{6}$. Identifying landowner characteristics associated with an interest in timber management, harvest, and contracts may help policy makers assess and modify policies and programs.

\section{Expected Results}

A number of studies have investigated landowner characteristics that are associated with management and harvesting activities, timber supply, and whether landowners are profit and/or utility maximizers. These past studies along with economic theory suggest a number of variables that could be significant in this analysis.

\section{Expectations on Willingness to Consider Future Timber Management and Harvesting}

A number of landowner characteristics were expected to influence future management and harvesting intentions. Economies

\footnotetext{
"Personal communication with R. Gaube, Prairie Farm Rehabilitation Administration, through D. Dosman, 19 May, 1993.

sPersonal communication with V. Begrand, Canadian Forest Service, on 24 August, 1993.

${ }^{6}$ The Farm Woodlot Association of Saskatchewan (FWAS) commissioned a report to describe and analyze NIPF wood supply in the province (Harding 1989 ) and Saskatchewan Agriculture Development Fund commissioned another to investigate the potential of private forests in Saskatchewan to meet timber demand (FWAS 1991).
} 
of scale associated with larger holdings are expected to result in a positive correlation between size of land holdings and management and harvesting activity (Jamnick and Beckett 1988; Binkley 1981; Carlen and Muller 1985). Distance between the respondent's residence and his/her woodlot is expected to be negatively correlated with the likelihood of timber management and harvest. This may be due to difficulties encountered by absentee landowners when arranging for timber harvesting and marketing (Carlen and Muller 1985; Jamnick and Beckett 1988). The length of property ownership by the respondent's family is expected to be positively correlated to harvest. This may be due to the increasing likelihood of historical precedent for timber harvest as the length of tenure increases. Respondents with longer tenures may be more likely to have experience and knowledge of wood management and harvest techniques than others (Jamnick and Beckett 1988).

Increased farm diversity is expected to be positively correlated to timber management and harvest. Diversified farmers are more likely to have the equipment and skills that are needed for a new operation. Increased diversification may also imply a more innovative farmer who may be more likely to regenerate following harvest (Straka and Doolittle 1988). Similarly, a positive correlation was expected between education and willingness to manage and harvest timber. Educated people may be better informed and more aware of opportunities.

Previous research on the relationship between owner's age and forest management and harvest is inconclusive. Binkley (1981) found age to be positively correlated to harvest, and explained this phenomenon by noting that if trees are considered an investment then, as the remaining lifespan of older people shortens, they are more likely to liquidate their investments. Carlen and Muller (1985) found age to be negatively correlated to timber harvest and noted that old age often leads to declining strength thereby causing older people to be less likely to harvest themselves. However, older people may be more likely to sell standing trees. Carlen and Muller (1985) also suggested that a desire of landowners to leave standing timber for the next generation may result in a negative correlation.

The number of consumptive (e.g., logging, grazing) and nonconsumptive (e.g., aesthetic enjoyment) uses of forests were expected to be, respectively, positively and negatively correlated with timber management and harvesting. Respondents who have used their forest consumptively may be more willing to manage and harvest their timber, whereas those who have used it non-consumptively may gain more utility from non-timber benefits associated with their forests than from potential revenue from their timber.

\section{Expectations on Willingness to Enter Management and Harvest Contracts}

Siegel (1973) and Meyer et al. (1986) point out that contracts have been used for some time in the southern United States to encourage sustainable forest management. Different contracts have been developed for management and harvesting of forests. In this study, willingness to allow someone else to manage or harvest a tract of forest was interpreted as an indication of willingness to enter into a contract. No previous studies were found that relate private forest owner characteristics to their willingness to enter into timber contracts. However, economic theory and intuition suggest that distance, forest tract size, level of diversity, age, and prior experience could be significant factors.
A positive correlation was expected between the distance from the respondents' residence to their land, and their willingness to consider a timber contract. Travel would increase the costs of timber management and harvest incurred by absentee landowners, causing them to be more willing to arrange for someone else to manage and harvest their forest. Furthermore, forest size was expected to be positively correlated with willingness to consider a timber contract. The time commitment required for landowners, who generally have jobs away from their farms and/or woodlots, to manage and harvest large tracts of timber could be prohibitive and cause them to enter into contracts. Landowners operating more diverse farm operations were thought to be more likely to have the skills and equipment required to manage a forest. Thus, a negative correlation was expected between level of diversity and willingness to consider a timber contract. The physical demands associated with timber management and harvest suggested that age would be positively correlated to willingness to enter a timber contract. Past experience was also expected to be related to willingness to enter a timber contract. Landowners who had allowed someone else to harvest their timber in the past would be more likely to have the experience and expertise required to enter into a contract in the future. Also, as the length of family tenure increases, the likelihood that landowners had been involved in a harvest contract in the past would increase, thus a positive correlation was expected between length of family tenure and willingness to enter a timber contract.

\section{Expectations on Contract Characteristics}

Contracts for various types of services can generally be described in terms of five characteristics: the party with whom the contract is entered, the duration of the contract, the method of payment for services received by the landowners, the method of payment to the landowner for the timber they sell, and the condition of the land at the end of the contract term. There were no a priori expectations in this study as to landowner characteristics that may be correlated to preferences for various contract characteristics.

\section{Data Collection}

The population for this study was identified as those persons who owned at least 16 ha of bush ${ }^{7}$ within one quarter, or continuous between quarters, within $100 \mathrm{~km}$ of Meadow Lake, Saskatchewan. A minimum bush requirement was intended to reflect economies of scale associated with timber harvest. Sixteen ha was selected in accordance with the minimum bush requirement identified by the Canadian Forest Service for inclusion in their private lands program. Mistik Management Ltd. ${ }^{8}$ recommended a maximum distance of $100 \mathrm{~km}$ from the mill site to reflect reasonable haul distances. Aerial photos were examined to identify land with adequate bush cover in the target area. These forested areas were then cross matched to township maps to identify the land owners. Since available aerial photography for the region was taken between 1979 and 1982, some of the land had been cleared subsequent to the time the photos were taken.

\footnotetext{
'The term "bush" is frequently used in Saskatchewan to refer to private forests. ${ }^{8}$ Mistik Management Ltd. is the company that runs the woodlands divisions of the Millar Western Pulp Mill in Meadow Lake and Norsask Forest Products, a sawmill in Meadow Lake.
} 
A random sample was drawn from the population of 1970 landowners and each respondent was surveyed using a personal interview format ${ }^{9}$. A target of 100 interviews was set and 133 names were drawn randomly from the population to try and achieve the target sample size. In total, 89 persons were interviewed $^{10}$.

The survey questionnaire was composed of three parts. Respondents were first asked to inventory their landholdings and farm operations. Part two contained questions pertaining to historical, current, and future intentions for forest usage and an assessment of the landowner's familiarity with woodlots. The third part allowed an investigation of the use of timber contracts. Landowners were asked to identify their preferences for a series of timber contract options including four different contracting agencies. The four agencies presented were a landowner organization, a forest products company, a government agency, and an independent contractor.

\section{Estimation of Models}

Logit models were estimated in order to analyze the effect of landowner characteristics on their preferences. The logit model uses the logistic distribution and takes the form:

$$
F(Z)=\frac{e^{2}}{1+e^{2}}
$$

where $Z$ is a function of landowner characteristics (Maddala 1983).

A number of logit models were developed to provide information on relationships between landowner characteristics and harvesting and management intentions. Further models attempted to predict whether respondents would prefer to manage and harvest their forest land themselves or have someone else manage and harvest it for them. A number of variables that were hypothesized to be potentially important factors were not highly significant and were removed from the final models. The variables included in the final models were defined in (Table 1).

Several specification tests were used to assess the accuracy of the regressions. Overall significance was assessed using the percent predicted correct and other statistical tools $\mathrm{s}^{11}$. Variance decomposition analysis indicated that collinearity ${ }^{12}$ was not a problem in the data.

\section{Results}

Results suggest that there is significant interest among woodlot owners in developing the private forest sector in northwest Saskatchewan. Although only approximately one quarter of the respondents had harvested wood from their land in the past ten years, and less than $10 \%$ had sold timber, approx-

\footnotetext{
${ }^{9}$ More reliable results were expected through personal interviews than through mail questionnaires or telephone interviews because the survey asked detailed questions about inventory and future intentions.

${ }^{10} \mathrm{Of}$ the 44 people drawn but not sampled 16 had cleared their land and no longer met the minimum bush requirement; 8 people had sold their land to others already included in the population; 8 people could not be located; and 12 people were not available for miscellaneous reasons.

"A likelihood-ratio test statistic, Maddala's R-squared and McFadden's R-squared were also calculated but are not included in the tables of results.

${ }^{12}$ Collinearity refers to the case when two or more explanatory variables are highly correlated, making it difficult or impossible to isolate their individual effects on the dependent variable.
}

\begin{tabular}{ll}
\hline Table 1. Definition of variables used in logit models \\
\hline Variable name & Definition \\
\hline $\begin{array}{l}\text { Age } \\
\text { Divers }\end{array}$ & $\begin{array}{l}\text { Age of the respondent } \\
\text { \# of different farm enterprises the respondent in which } \\
\text { is involved } \\
\text { Family }\end{array}$ \\
Past & $\begin{array}{l}\text { one parcel of the current land base } \\
\text { used for past harvesting activity }\end{array}$ \\
Trees & $\begin{array}{l}\text { 100's of acres of trees owned by respondent } \\
\text { The number of ways respondents use their forest land } \\
\text { (consumptive and non-consumptive) }\end{array}$ \\
\end{tabular}

imately half indicated that they would consider harvesting trees in the future. There was also considerable interest in timber contracts with approximately half of the respondents indicating they would consider a timber management or harvest contract in the future. Landowners appeared to be well suited to developing this sector. The mean landholding was approximately 324 ha, and nearly 109 ha of this was bush land. Many of the landholders are likely to have some of the skills and equipment needed to meet this demand since three quarters of the respondents owned at least one tractor and nearly half were involved in two or more farm enterprises. ${ }^{13}$

Results of the model estimation show reasonably high levels of overall significance with the percent predicted correct ranging between 64 and 70 percent. The results from logit models that regressed, respectively, the willingness to consider management and harvesting in the future on selected landowner characterstics were listed in (Tables 2 and 3). The variables family and uses were, respectively, significantly negatively and positively correlated with the dependent variable in both models. The degree of diversification was positively correlated with willingness to consider managing timber stands. The area of trees owned was not a highly significant factor in willingness to consider management; but, it was left in the final model because it had the expected sign, did not affect the other coefficients, and improved the model's forecasting ability.

Table 2. Logit results of the impact of selected characteristics on a landowner's willingness to consider managing their forest land in the future

\begin{tabular}{lccc}
\hline Variable & Coefficient & Standard error & $\rho^{1}=$ \\
\hline Constant & -0.87747 & 0.6651 & 0.18705 \\
Family & -0.29031 & 0.1090 & 0.00773 \\
Divers & 0.4892 & 0.2818 & 0.08254 \\
Uses & 0.51946 & 0.1952 & 0.00780 \\
Trees & 0.13252 & 0.1126 & 0.23914 \\
\hline
\end{tabular}

'A numerical estimate is significant at the $1 \%$ level if $\rho \leq 0.01$, at the $5 \%$ level if $\rho \leq 0.05$, and at the $10 \%$ level if $\rho \leq 0.10$.

Percent predicted correct $=70 \%$.

${ }^{13} \mathrm{~A}$ description of the summary statistics and preliminary results can be found in Salkie et al. (1993).

${ }^{14}$ The survey questions were designed to elicit information that could be used in multinomial logit models to identify landowner preferences between various timber contract characteristics. However, there was insufficient variation in the data given the sample size, for these models to produce significant results. 
Table 3. Logit results of the impact of selected characteristics on a landowner's willingness to consider harvesting their forest land in the future

\begin{tabular}{lccc}
\hline Variable & Coefficient & Standard error & $\rho^{1}=$ \\
\hline Constant & 0.28607 & 0.5624 & 0.61098 \\
Family & -0.21565 & 0.09784 & 0.02751 \\
Uses & 0.409252 & 0.1794 & 0.02257
\end{tabular}

'A numerical estimate is significant at the $1 \%$ level if $\rho \leq 0.01$, at the $5 \%$ level if $\rho \leq 0.05$, and at the $10 \%$ level if $\rho \leq 0.10$.

Percent predicted correct $=64 \%$.

Tables 4 and 5 list, respectively, the results from logit regressions that examined the relationship between landowners' characteristics and their interest in considering timber management and timber harvest agreements. The area of trees owned and the level of farm diversification were significant and negatively correlated with consideration of a management contract. Willingness to consider a harvest contract was positively correlated with both the length of family tenure of the land and the age of the landowner. Although it was not highly significant, past experience with a harvesting contractor was left in the model that analyzed willingness to consider a timber management contract because it improved the model's forecasting ability and did not affect the other coefficients in the model.

Summary statistics of the responses to questions on landowner preferences for contract characteristics identified some general preferences that are presented in Tables 6 through $9^{14}$. When presented with various agencies, respondents showed a general preference for landowner organizations as a managing agency and an independent contractor as a harvester. Over half of the respondents preferred to pay for management and/or harvesting services received through a crop share arrangement. Nearly $60 \%$ of the respondents favoured a contract duration of between one and five years. Over $60 \%$ of the respondents wanted their land to be left with young growth established at the end of the contract term. The strongest preference for payment method for timber sold was to receive a periodic land lease payment and be paid for the timber at the time of harvest. Approximately $35 \%$ of the respondents favoured this payment method.

\section{Discussion}

Several of the relationships, identified in this study, between landowners characteristics and behaviour did not concur with results of other studies and a priori expectations. In fact, some characteristics had opposite than expected signs. Some of the discrepancies, in terms of the significance of variables, between the results of this study and those from previous work may be due to sample size ${ }^{15}$. However, a number of other factors may explain deviations between expected and actual results. Some of these reasons are outlined below.

Table 4. Logit results of the impact of selected characteristics on a landowner's willingness to consider entering a timber management agreement in the future

\begin{tabular}{lccc}
\hline Variable & Coefficient & Standard error & $\rho^{1}=$ \\
\hline Constant & 1.0197 & 0.5082 & 0.04479 \\
Trees & -0.35475 & 0.1375 & 0.00989 \\
Divers & -0.45880 & 0.2653 & 0.08373 \\
Past & 0.44907 & 0.3691 & 0.22368 \\
\hline
\end{tabular}

${ }^{1}$ A numerical estimate is significant at the $1 \%$ level if $\rho \leq 0.01$, at the $5 \%$ level if $\rho \leq 0.05$, and at the $10 \%$ level if $\rho \leq 0.10$.

Percent predicted correct $=69 \%$.
Table 5. Logit results of the impact of selected characteristics on a landowner's willingness to consider entering a timber harvesting agreement in the future

\begin{tabular}{lccc}
\hline Variable & Coefficient & Standard error & $\rho^{1}=$ \\
\hline Constant & -1.5541 & 0.8100 & 0.05503 \\
Age & 0.39772 & 0.1974 & 0.04394 \\
Family & 0.17442 & 0.1047 & 0.09559 \\
\hline
\end{tabular}

${ }^{1} \mathrm{~A}$ numerical estimate is significant at the $1 \%$ level if $\rho \leq 0.01$, at the $5 \%$ level if $\rho \leq 0.05$, and at the $10 \%$ level if $\rho \leq 0.10$.

Percent predicted correct $=69 \%$.

\begin{tabular}{lcc}
\hline Table 6. Preference for contract duration & & \\
\hline Contract length & Frequency & $\%$ \\
\hline$<1$ year & 20 & 23.0 \\
1-5 years & 51 & 58.6 \\
6-15 years & 11 & 12.6 \\
15-30 years & 4 & 4.6 \\
$>30$ years & 1 & 1.1 \\
Missing values & 2 & \\
\hline
\end{tabular}

Table 7. Preference for land condition at contract end

\begin{tabular}{lcc}
\hline Land condition & Frequency & $\%$ \\
\hline Same volume of timber as at contract outset & 11 & 12.9 \\
No regeneration & 19 & 22.4 \\
Young growth established & 52 & 61.2 \\
Condition of the land is not important & 3 & 3.5 \\
Missing values & 4 & \\
\hline
\end{tabular}

Table 8. Preferred payment option for management/harvesting services received

\begin{tabular}{lcc}
\hline Option & Frequency & $\%$ \\
\hline Cash for service & 26 & 29.9 \\
Crop share & 45 & 51.7 \\
Giving the managing agency an option & 16 & 18.4
\end{tabular}

to purchase

Missing values

2

Table 9. Preference for payment received for timber harvested

\begin{tabular}{lcr}
\hline Payment method $^{\mathbf{1}}$ & Frequency & \multicolumn{1}{c}{$\%$} \\
\hline Option 1 & 23 & 26.4 \\
Option 2 & 5 & 5.7 \\
Option 3 & 31 & 35.6 \\
Option 4 & 11 & 12.6 \\
Cash at time of harvest & 17 & 19.5 \\
Missing values & 2 & \\
\hline
\end{tabular}

'The payment option were defined as:

Option 1: A contract in which they are paid for all standing timber initially and receive a periodic lease payment for the land throughout the contract period. Option 2: A contract in which both land and timber are leased through a periodic payment.

Option 3: A contract in which the land is leased with a periodic payment and the timber is paid for at the time it is harvested.

Option 4: A contract in which a periodic payment is paid based on the average annual growth of timber. At the time of timber harvest adjustments are made for over or under payment. 


\section{Willingness to Consider Future Timber Management and Harvesting}

Diversity was the only landowner characteristic that yielded the expected sign with regards to willingness to consider future timber management or harvesting. A number of other variables were not significant in either model including: distance between residence and forest, age, and education. The number of years in the family and forest uses yielded significant results with unexpected signs.

Education level may not have been significant because formal measures of education were used. The grade level achieved may not accurately reflect respondents' effective education level because in many areas of rural Saskatchewan formal education was, historically, only available until grade eight. Regarding the variable distance, Saskatchewan is a large province and urban centres are often some distance from rural communities. People may more frequently drive long distances to shop and attend school than they do in other locations such as the Maritimes where Jamnick and Beckett (1988) conducted their research, and thus may also be indifferent to driving long distances to their forest land holdings. Forest area owned was likely not a significant factor in willingness to manage or harvest because the population was pre-defined as owners with at least 16 ha of trees. This differed from studies by Jamnick and Beckett (1988) in which the sample was not restricted by forest area owned, and by Binkley (1981) in which, although the sample was biased towards large forest holdings, it was not truncated by a minimum forest holding.

The variable family was significantly negatively correlated to consideration of future harvest; this is contrary to work by Jamnick and Beckett (1988) in New Brunswick where length of family tenure was positively correlated to woodlot harvesting activity. This difference may result from the different ways in which private forests have historically been used in the two provinces. Jamnick and Beckett suggested that, as the length of family tenure increased, the likelihood of past harvesting activity also increased. Thus, past precedent would encourage the respondent to harvest their timber. However, little harvesting activity has taken place on private land in Saskatchewan historically. Thus, as the length of family tenure increased, the likelihood that the forest had been used for timber management and harvesting may not increase; rather, the likelihood that the land had been used for non-timber uses may increase. Therefore, in the case of Saskatchewan, past precedent and experience suggest that landowners may be less likely to consider future harvest as length of family tenure increases. Although the two studies found opposite signs for the variable family, the logic and reasoning behind both results are the same.

The expected correlation between consumptive and non-consumptive forest uses and willingness to consider forest management and harvesting was not observed. The number of nonconsumptive, consumptive, and total uses (consumptive and non-consumptive) of the forest were all positively correlated to willingness to consider forest management and harvesting, with the strongest correlation being with total number of uses. Respondents may consider private forests to be either waste land or a resource. These results suggest that those who have used the forest in any way consider it a resource and may consid-

${ }^{15}$ Personal interviews were used to collect data thus our sample size was smaller than those of previous works. er managing or harvesting it. Those who have not used their forest land in the past may not consider it a resource, and may therefore not consider using it in the future.

\section{Willingness to Enter Management and Harvest Contracts}

The level of diversity of farm operations exhibited the expected negative correlation to willingness to let someone else manage the forest. Furthermore, age conformed to expectations and was positively correlated to willingness to consider letting someone else harvest timber stands. Past experience conformed with a priori expectations and was positively correlated with willingness to consider a timber contract. Although not highly significant, past experience with a timber contract was positively correlated with willingness to consider a timber management agreement. The length of family tenure was positively correlated with willingness to consider a harvesting contract; however this result was incongruous with the negative correlation observed between length of family tenure and willingness to consider future timber management or harvest reported above. This apparent discrepancy may be explained by the hypothetical nature of the question regarding willingness to enter a timber contract. All landowners were asked to express their willingness to enter into a contract assuming that they were considering timber management and harvesting. Thus, if in the past, landowners had not been involved with these activities, their lack of experience may encourage them to enter into contracts for future timber management and harvesting, rather than conducting the operation themselves.

Neither the area of trees owned nor the distance from respondents' residence to their forest land yielded the expected results. Contrary to expectations, the area of trees owned was negatively correlated to consideration of a management contract. This may reflect the fact that the population was restricted to those landholdings with more than 16 ha of trees ${ }^{16}$. A 16 ha forest may be too small to meet economies of scale associated with forest management. However, the area of trees was not significantly related to willingness to consider a harvest contract. Sixteen ha may be a large enough tract of forest to meet economies of scale associated with forest harvesting. Furthermore, distance was not a significant explanatory variable in willingness to consider timber management or harvest contracts. This may be due to cultural attitudes towards distance as described previously.

\section{Conclusions and Implications}

Recent technological development has created a new demand for aspen pulpwood in the northwest region of Saskatchewan. Industrial forest product companies are considering private woodlots as an alternative supply of fibre and are interested in knowing if landowners are willing and able to supply them with fibre through time. Policy makers are interested in alternative policy options that could be used to encourage regional development. It is, therefore, important to identify landowners who may be interested in supplying timber and to evaluate alternative policies and programs that could be used to encourage sustainable forest management.

Some of the results presented above differ from woodlot studies that have been undertaken in other parts of North America;

${ }^{16}$ The mean forest holding was 109 ha; however, nearly $75 \%$ of those interviewed owned less than 81 ha of trees and only $15 \%$ owned more than 121 ha. 
however, economic theory can be used to explain both these results and the results of previous studies. The broad significance of the variability of results is that findings should not be extrapolated between regions. Economic decisions are made in a broad environment that includes: regional socio-demographic characteristics, the historical development of the region, landowner preferences, and the macro-environment within which decisions are made. Rural Saskatchewan developed differently than the Maritimes and many other regions of North America. Forestry is generally less important to Saskatchewan's economy and the level of non-industrial private forest ownership is lower than in other regions with more developed private forestry sectors. In many of these regions, the private forest sector developed simultaneously with agriculture and industrial forestry. Similarly, government programs and subsidies vary among provinces and can distort the decision making environment.

With the emergence of a new valuable resource on private woodlands, it is an opportune time to review government policy, including agricultural policy and the Saskatchewan Forest Act, to identify potential land use biases. Rural Saskatchewan and the farm culture are in transition. Although respondents typically were raised on a farm, less than $50 \%$ currently farm fulltime and only $22.5 \%$ farm part time. The average respondent was between 46 and 55 years old and had some high school education. As the land is taken over by younger people, the level of education and ownership objectives may also change. These changes may already be apparent from the decline in the number of respondents farming compared to the number that grew up on a farm, and the discrepancy between historical harvest levels and interest in future timber harvests. Along with this transition, government policy is also likely to change in response to increasing pressure from abroad, and concerns about government debt.

Forest policy, such as tenure allocation and stumpage policies, has been identified as a possible impediment to the development of private woodlots. Restructuring tenure could prevent problems associated with monopsonies, lack of log markets, and information exchange. Government policy may also have to address a variety of issues relating to increased woodlot harvesting levels. The harvest of private forests will affect the environment through changes to total forest cover and watershed. It is necessary to identify regulatory options and remove market impediments to facilitate the development of private timber markets while minimizing possible detrimental impacts.

Further research should address a number of assumptions included in this study. Landowners with less than 16 ha may be willing to manage and harvest timber in future. For example, new varieties of aspen may provide landowners with an opportunity to intensively manage small stands for profit or forest belts may be used to produce timber. Furthermore, the assumption that $100 \mathrm{~km}$ is a reasonable haul distance for aspen is based on current economic conditions in the region. In other areas of the prairies, $200 \mathrm{~km}$ hauls are not unusual. As the demand for aspen changes, the definition of a reasonable haul distance in northwestern Saskatchewan may also change. Future studies should also consider the impact of stand attributes, including tree species, quality and volume, on landowner preferences for forest management and harvesting. Markets for private softwood products are more developed than for hardwoods, yet new demand is primarily for hardwoods. Studies could investigate landowner characteristics that are associated with past management and harvesting of softwoods and assess whether the species mix affects respondents' interest in future timber management and harvesting.

Finally, this study only investigated timber contracts as a means of encouraging sustainable timber management on private land. Several other mechanisms could also be used. Alternative mechanisms such as landowner organizations, marketing boards, and changes to the Forest Act should be investigated. Further, some of the macro policy factors that affect private land forestry were identified but not analyzed. Work is required to investigate the full impact that factors such as agricultural policy, taxation, and forest policy have on land use decisions.

The results of this study suggest there is potential for private woodlot development that may contribute to rural development. However, the economic development of rural Saskatchewan is affected by a combination of cultural, technological, and current policy factors. If future policies are to further social welfare they should consider as many of these changes as possible.

\section{Acknowledgements}

Funding for this research was provided through the CanadaSaskatchewan Partnership Agreement in Forestry. The authors would like to thank Vic Begrand, Dave Harman, Donna Dosman, and Vic Adamowicz for their help. The time and effort given by survey respondents is also gratefully acknowledged. The authors have benefited from the comments of Derek MacFarlane and an anonymous reviewer.

\section{References}

Binkley, C.S. 1981. Timber Supply From Private Nonindustrial Forests: A Microeconomic Analysis of Landowner Behaviour. Bulletin No. 92, School of Forestry and Environmental Studies, Yale University, New Haven, Connecticut.

Carlen, O. and A. Muller. 1985. What Determines the Private Forest Owner's Decision To Cut - An Econometric Study Based on Swedish Survey Data. Arbetrsrapport 44, Sveriges Lantbruksuniversitet Institutionen for Skogeskonomi.

Dennis, D.F. 1990. A Probit Analysis of the Harvest Decision Using Pooled Time-series and Cross-sectional Data, Journal of Environmental Economics and Management, 18: 176-187.

Dennis, D.F. 1989. An Economic Analysis of Harvest Behaviour: Integrating Forest and Ownership Characteristics, Forest Science, 35(4): 1088-1104.

Duerr, W.A., D.E. Teeguarden, N.B. Christiansen and S. Guttenberg. 1979. Forest Resource Management: Decision-Making Principles and Cases. W.B. Saunders Company, Philadelphia.

Farm Woodlot Association of Saskatchewan. 1991. A Current Evaluation of Saskatchewan's Private Forest Resources. A report prepared for the Saskatchewan Agriculture Development Fund, Regina, Saskatchewan.

Greene, J.L. and K.A. Blatner. 1986. Identifying Woodland Owner Characteristics Associated With Timber Management, Forest Science, 32(1): 135-146.

Harding, L.R. 1989. NIPF Wood Supply: Description and Analysis, An unpublished report prepared for the Farm Woodlot Association of Saskatchewan.

Hyberg, B.T. and D.M. Holthausen. 1989. The Behavior of Nonindustrial Private Forest Landowners, Canadian Journal of Forest Research, 19: 1014-1023.

Jamnick, M.S. and D.R. Beckett. 1988. A Logit Analysis of Private Woodlot Owner's Harvesting Decisions in New Brunswick, Canadian Journal of Forest Research, 18: 330-336.

Maddala, G.S. 1983. Limited-dependent and Qualitative Variables in Econometrics. Economic Society Monographs No. 3. Cambridge University Press, New York. 
Messmer, M., M. Percy, W.E. Phillips and D. Boylen. 1990. An Economic Analysis of Wood Supply From Private Land in Alberta. Project 23908-88, Canada-Alberta Forest Resource Development Agreement, and Project Report No., 90-07, Department of Rural Economy, University of Alberta.

Meyer, R.D., W.D. Klemperer and W.C. Siegel. 1986. Cutting Contracts and Timberland Leasing, Journal of Forestry, 84(12): 35-38.

Romm, J., R. Tuazon and C. Washburn. 1987. Relating Forestry Investment to the Characteristics of Nonindustrial Private Forestland Owners in Northern California, Forest Science, 33(1): 197-209.
Salkie, F.J., M.K. Luckert and W.E. Phillips. 1993. Private Woodlot Survey Results for Northwestern Saskatchewan. Project Report No. 93-06, Department of Rural Economy, University of Alberta. Siegel, W.C. 1973. Long-term Contracts for Forest Land and Timber in the South, Forest Service Research Paper SO-87, USDA.

Statistics Canada. 1993. Agriculture Economic Statistics. Catalogue Number 21-603.

Straka, T.J. and M.L. Doolittle. 1988. Propensity of Nonindustrial Private Forest Landowners to Regenerate Following Harvest: Relationship to Socioeconomic Characteristics, Including Innovativeness, Resource Management and Optimization, 6(2): 121-128. 